\title{
Synthesis, Crystal Structure Refinement, and Electrical Conductivity of $\mathrm{Pb}_{(8-x)} \mathrm{Na}_{2} \mathrm{Sm}_{x}\left(\mathrm{VO}_{4}\right)_{6} \mathrm{O}_{(x / 2)}$
}

\author{
Tatiana M. Savankova, ${ }^{1}$ Lev G. Akselrud, ${ }^{2}$ Lyudmyla I. Ardanova, ${ }^{3}$ Alexey V. Ignatov, ${ }^{1}$ \\ Eugeni I. Get'man, ${ }^{1}$ Roman E. Gladyshevskii, ${ }^{2}$ and Stanislav N. Loboda ${ }^{1}$ \\ ${ }^{1}$ Department of Inorganic Chemistry, Donetsk National University, 24 Universitetskaya, Donetsk 83001, Ukraine \\ ${ }^{2}$ Department of Inorganic Chemistry, Ivan Franko National University of Lviv, 6 Kyryla i Mephodiya Street, Lviv 79005, Ukraine \\ ${ }^{3}$ Department of Chemistry and Geology, Minnesota State University, 241 Ford Hall, Mankato, MN 56001, USA
}

Correspondence should be addressed to Lyudmyla I. Ardanova; lyudmyla.stackpool@mnsu.edu

Received 23 February 2014; Revised 21 May 2014; Accepted 23 May 2014; Published 17 June 2014

Academic Editor: M. Fernanda Carvalho

Copyright (C) 2014 Tatiana M. Savankova et al. This is an open access article distributed under the Creative Commons Attribution License, which permits unrestricted use, distribution, and reproduction in any medium, provided the original work is properly cited.

Solid solutions of $\mathrm{Pb}_{(8-x)} \mathrm{Na}_{2} \mathrm{Sm}_{x}\left(\mathrm{VO}_{4}\right)_{6} \mathrm{O}_{(x / 2)}$ were studied using X-ray diffraction analysis including Rietveld refinement and scanning electron microscopy and by measuring their electrical conductivity. Crystal structure of the solid solutions was refined and the solubility region $0 \leq x \leq 0.2$ was determined for samarium substitution for lead under the scheme $2 \mathrm{~Pb}^{2+}+\square \rightarrow 2 \mathrm{Sm}^{3+}+\mathrm{O}^{2-}$. The influence of degree of substitution on the electrical conductivity of solid solutions was established.

\section{Introduction}

Compounds with the apatite-type structure $\mathrm{M}_{10}\left(\mathrm{ZO}_{4}\right)_{6} \mathrm{X}_{2}$ (where $\mathrm{M}=\mathrm{Na}^{+}, \mathrm{K}^{+}, \mathrm{Ca}^{2+}, \mathrm{Sr}^{2+}, \mathrm{Ba}^{2+}, \mathrm{Pb}^{2+}, \mathrm{Cd}^{2+}, \mathrm{Eu}^{3+}, \mathrm{Y}^{3+}$, $\mathrm{La}^{3}$, etc.; $\mathrm{Z}=\mathrm{Si}^{4+}, \mathrm{Ge}^{4+}, \mathrm{P}^{5+}, \mathrm{V}^{5+}, \mathrm{As}^{5+}, \mathrm{S}^{6+}, \mathrm{Cr}^{6+}$, etc.; $\mathrm{X}=$ $\mathrm{OH}^{-}, \mathrm{F}^{-}, \mathrm{Cl}^{-}, \mathrm{Br}^{-}, \mathrm{I}^{-}, \mathrm{O}^{2-}$, vacancy, etc.) are characterized by different properties and may be used as bioactive, laser and luminescent materials, sensors, solid electrolytes, adsorbents, and catalysts [1-4], among other uses. The apatite structure features two structurally nonequivalent positions $\mathrm{M}(1)$ and $\mathrm{M}(2)$, present in a ratio of $4: 6$ in the formula unit. The $\mathrm{M}(1)$ position ( $4 \mathrm{f}$ position) is surrounded by nine oxygen atoms of $\mathrm{VO}_{4}$ tetrahedra. The position of $\mathrm{M}(2)$ (6h position) is surrounded by six oxygen atoms of $\mathrm{VO}_{4}$ tetrahedra and one atom X (2a position) located in the channel of the structure. The central axis of triangles formed by ions in position $\mathrm{M}(2)$ coincides with $z$ axis. Repetition of this structure along the $z$ axis results in formation of channels, along which anions (X) can be located [5].

This structure makes isomorphous substitutions possible by different elements in different sites. Formation of solid solutions changes not only the nature of chemical bonding and interatomic distances but the physical and chemical properties of the substances as well. Accordingly, the synthesis and study of solid solutions with the apatite structure are a way to produce new functional materials with improved physical and chemical characteristics and to address one of the fundamental problems of modern chemistry, that of establishing the correlation between composition, structure, and property.

Substitutions of rare earth elements for alkaline earth elements in compounds with apatite structure have been well-studied (e.g., [6-8]). However, despite the fact that the value of ionic radius of lead is close to the radii of alkaline earth ions, there is no information about the substitution of rare earth elements for lead in the systems $\mathrm{Pb}_{(10-x)} \operatorname{Ln}_{x}\left(\mathrm{ZO}_{4}\right)_{6}(\mathrm{OH})_{(2-x)} \mathrm{O}_{x}$ in the literature. Possibly, this is due to the presence of the stereochemically active lone electron pairs on lead atoms, which prevent substitution under the scheme $\mathrm{Pb}^{2+}+\mathrm{OH}^{-} \rightarrow \mathrm{Ln}^{3+}+\mathrm{O}^{2-}$. However, substitutions $2 \mathrm{~Pb}^{2+}+\square \rightarrow 2 \mathrm{Sm}^{3+}+\mathrm{O}^{2-}$ apparently are possible for $\mathrm{Pb}_{8} \mathrm{Na}_{2}\left(\mathrm{VO}_{4}\right)_{6}$ as well as for previously described $\mathrm{Pb}_{8} \mathrm{Na}_{2}\left(\mathrm{PO}_{4}\right)_{6}$ [9]. This is due to absence of $\mathrm{OH}^{-}$groups in the structure and a smaller number of unshared electron pairs in lead atoms compared to $\mathrm{Pb}_{10}\left(\mathrm{VO}_{4}\right)_{6}(\mathrm{OH})_{2}$. Advantages of $\mathrm{Pb}-\mathrm{Na}$ systems are twofold. Substantially lower temperature 


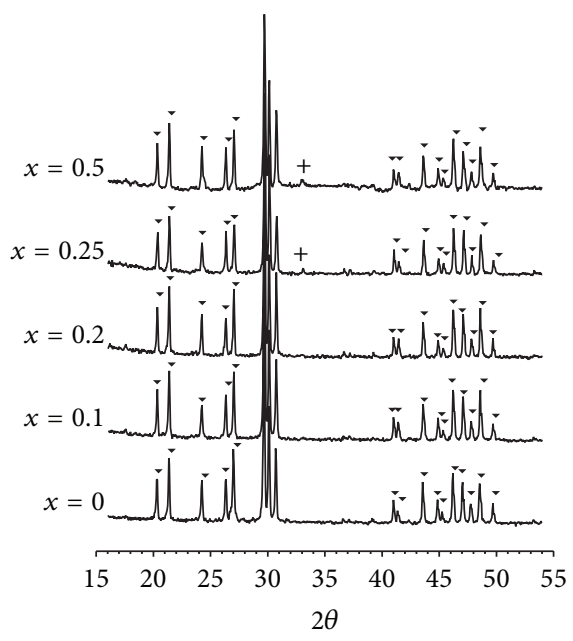

(a)

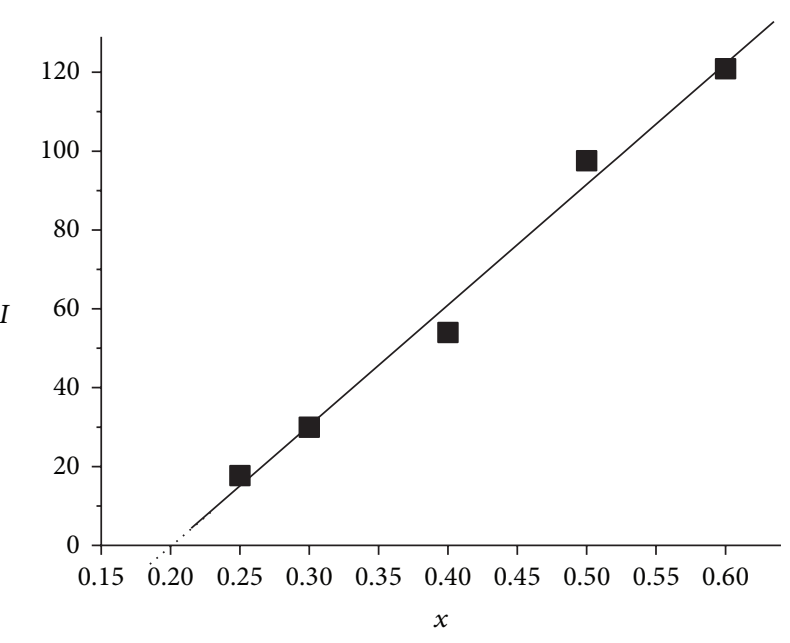

(b)

FIGURE 1: (a) X-ray patterns for $\mathrm{Pb}_{(8-x)} \mathrm{Na}_{2} \mathrm{Sm}_{x}\left(\mathrm{VO}_{4}\right)_{6} \mathrm{O}_{(x / 2)}$ ( $\boldsymbol{\nabla}$ : phase with apatite structure, +: phase with $\mathrm{SmVO}_{4}$ structure); (b) graph of the absolute intensity of $\mathrm{hkl}=200$ line of $\mathrm{SmVO}_{4}$ as a function of $x$ in the formula.

of synthesis for lead sodium apatite [10, 11] compared to alkaline earth apatite-type compounds [6] simplifies the method of synthesis and promotes the production of fine grains. Additionally, the structural channels of these lead apatite compounds are free, which would be expected to favor oxygen conductivity according to the substitution scheme presented previously. Thus, we anticipate that $\mathrm{Ln}^{3+}$ substitutions are feasible in $\mathrm{Pb}-\mathrm{Na}$ apatites.

The purpose of this work, therefore, was to study the substitution of samarium $\left(\mathrm{Sm}^{3+}\right)$ for lead in lead sodium vanadate $\mathrm{Pb}_{8} \mathrm{Na}_{2}\left(\mathrm{VO}_{4}\right)_{6}$. It is known that vanadates with apatite structure form and sinter at much lower temperatures than phosphate apatites. Vanadate apatites also have up to an order of magnitude greater electrical conductivity compared with phosphate apatites [11]. Since conductivity determination is part of the characterization we report here, vanadate apatites are advantageous for this study.

\section{Experimental Procedure}

A series of samples $\mathrm{Pb}_{(8-x)} \mathrm{Na}_{2} \mathrm{Sm}_{x}\left(\mathrm{VO}_{4}\right)_{6} \mathrm{O}_{(x / 2)}$ with the values of $x=0,0.05,0.10,0.15,0.20,0.25,0.30,0.40,0.50$, and 0.60 have been investigated. Reagents that have been used are $\mathrm{PbCO}_{3}$ (99.99\% pure) and $\mathrm{NH}_{4} \mathrm{VO}_{3}$ (99.5\%) from Alfa Aesar and $\mathrm{Na}_{2} \mathrm{CO}_{3}$ (99.8\%) and $\mathrm{Sm}_{2} \mathrm{O}_{3}$ (99.99\%) from Acros Organics. Powders were weighed on an analytical balance, mixed, and then ground for 20 minutes in an agate mortar. Then, the mixture was transferred into alumina crucibles and calcined for one hour at $300^{\circ} \mathrm{C}$ and $500^{\circ} \mathrm{C}$ each and then at $600^{\circ} \mathrm{C}$. Samples were analyzed by X-ray diffraction after every 5-6 hours of calcination at $600^{\circ} \mathrm{C}$, which was carried out until a consistent phase composition was attained. The synthesis was completed in 67 hours at $600^{\circ} \mathrm{C}$. XRD analysis was conducted on a Rigaku Ultima IV diffractometer $(\mathrm{CuK} \alpha$ radiation, Ni-filter) with the scanning rate of $2^{\circ}(2 \theta)$ per minute.
Phase composition analysis was carried out using the PDXL software. The unit cell parameters were calculated by the least squares method based upon 17 clearly displayed peaks with the angular scan rate of counter $1^{\circ}$ per minute $(2 \theta)$. Silicon was added to samples as an internal standard. Rietveld refinement was then used to determine the crystalline structure by powder diffraction data. The angular range chosen for calculations was from 15 to $140^{\circ}(2 \theta)$. The angle increment and scanning rate were $0.02^{\circ}$ and $0.3^{\circ}$ per minute, respectively. The refinement was carried out using WinCSD software [14]. The reliability factors $R_{I}$ and $R_{p}$ for compositions with $x=0$ and 0.15 were equal to 0.055 , 0.097 and $0.048,0.088$, respectively. Infrared absorption spectra were recorded in the wave number range from 4000 to $400 \mathrm{~cm}^{-1}$ with a Bruker-Optics infrared spectrometer with Fourier transformer, using $\mathrm{KBr}$ pellets compressed at a pressure of $700 \mathrm{MP}$ (mass ratio 1:200). The grain size and composition, as well as elemental distribution on the grain surfaces, have been studied using a JSM-6490LV scanning electron microscope with INCA Penta FETx3 (OXFORD Instruments) energy dispersion spectrometer.

To measure electrical conductivity, the powders were pressed into the pellets with diameter of $0.8 \mathrm{~cm}$ at a pressure of $120 \mathrm{MPa}$ and sintered at $600^{\circ} \mathrm{C}$ for 50 hours. Silver was used as electrodes. Resistivity measurements were carried out with a LCR DE-5000 meter at $100 \mathrm{kHz}$ frequency while heating the samples from 300 to $600^{\circ} \mathrm{C}$ with a rate of $2^{\circ} / \mathrm{min}$.

\section{Results and Discussion}

Powder diffraction analyses show that only apatite diffraction lines are present in the composition range $0 \leq x \leq$ 0.2 (Figure 1(a)). In addition to peaks corresponding to the apatite structure, the peaks corresponding to a $\mathrm{SmVO}_{4}$ phase are found in the diffraction patterns of the samples with composition $x>0.2$ in the apatite formula. For $x>0.2$, 
TABLE 1: Unit cell parameters for solid solutions $\mathrm{Pb}_{8-x} \mathrm{Na}_{2} \mathrm{Sm}_{x}\left(\mathrm{VO}_{4}\right)_{6} \mathrm{O}_{x / 2}$.

\begin{tabular}{lcc}
\hline$x$ & $a(\AA)$ & $c(\AA)$ \\
\hline 0 & $10.057(2)$ & $7.327(2)$ \\
0.05 & $10.049(2)$ & $7.326(2)$ \\
0.10 & $10.045(1)$ & $7.326(1)$ \\
0.15 & $10.042(1)$ & $7.323(1)$ \\
0.20 & $10.040(2)$ & $7.323(2)$ \\
\hline
\end{tabular}

TABLE 2: Unit cell parameters for selected apatites.

\begin{tabular}{lccc}
\hline Composition & $a(\AA)$ & $c(\AA)$ & Reference \\
\hline $\mathrm{Pb}_{10}\left(\mathrm{VO}_{4}\right)_{6}(\mathrm{OH})_{2}$ & $10.2242(3)$ & $7.4537(3)$ & {$[12]$} \\
$\mathrm{Na}_{2} \mathrm{~Pb}_{8}\left(\mathrm{VO}_{4}\right)_{6}$ & $10.060(2)$ & $7.346(1)$ & {$[13]$} \\
$\mathrm{Na}_{2} \mathrm{~Pb}_{8}\left(\mathrm{VO}_{4}\right)_{6}$ & $10.059(3)$ & $7.434(2)$ & {$[11]$} \\
$\mathrm{K}_{2} \mathrm{~Pb}_{8}\left(\mathrm{VO}_{4}\right)_{6}$ & $10.111(2)$ & $7.448(1)$ & {$[13]$} \\
$\mathrm{Na}_{2} \mathrm{~Pb}_{8}\left(\mathrm{VO}_{4}\right)_{6}$ & $10.057(2)$ & $7.327(2)$ & Current paper \\
\hline
\end{tabular}

the intensity of the $\mathrm{SmVO}_{4}$ lines increases as the proportion of $\mathrm{Sm}_{2} \mathrm{O}_{3}$ in the mixture of initial components increases. Thus, based on the samples' phase composition data, the replacement of samarium for lead in the $\mathrm{Pb}-\mathrm{Na}$ apatite structure occurs in the range $0 \leq x \leq 0.2$. The refinement of the location of the single-phase region boundary was carried out using the "disappearing phase" method by plotting the absolute intensity of $\mathrm{hkl}=200$ line of the $\mathrm{SmVO}_{4}$ phase as a function of $x$ value (Figure 1(b)). Extrapolating the resulting straight line to a zero-intensity value for the $\mathrm{SmVO}_{4}$ peak, the limit of substitution of samarium for lead was found at $x=0.2$.

Incorporation of samarium into apatite structure is confirmed by the unit cell parameters presented in Table 1 . This data shows a decrease of the unit cell parameter $a$ (by $0.017 \AA$ with the precision 0.001-0.002 $\AA$ ) and $c$ within the error (by $0.004 \AA$ ) as the samarium content increases due to the smaller ionic radius of $\mathrm{Sm}^{3+}(1.132 \AA)$ compared to the radius of $\mathrm{Pb}^{2+}$ $(1.350 \AA)$, using the ionic radii of Shannon for coordination number 9 [15].

However, this small change ( 0.017 and $0.004 \AA$ for parameters $a$ and $c$, resp.) requires explanation, since the difference in the ionic radii is significant $(0.218 \AA)$. To explain what causes this phenomenon, a comparison of the values for the unit cell parameters for $\mathrm{Pb}_{10}\left(\mathrm{VO}_{4}\right)_{6}(\mathrm{OH})_{2}, \mathrm{Na}_{2} \mathrm{~Pb}_{8}\left(\mathrm{VO}_{4}\right)_{6}$, and $\mathrm{K}_{2} \mathrm{~Pb}_{8}\left(\mathrm{VO}_{4}\right)_{6}$ with apatite structure has been done (Table 2). As can be seen from the table, replacement of the alkali metals for lead results in significant reduction in values of the unit cell parameters not only in case of sodium but surprisingly in case of potassium as well, although the radius of $\mathrm{K}^{+}(1.550 \AA)$ is larger than the ionic radius of $\mathrm{Pb}^{2+}(1.350 \AA)$. Replacement of alkaline metals for lead in the structure of $\mathrm{Pb}_{10}\left(\mathrm{VO}_{4}\right)_{6}(\mathrm{OH})_{2}$ reduces the size of the apatite unit cells so significantly that the partial replacement of samarium (smaller in size than lead) for lead has almost no effect on the values of the unit cell parameters.

The reason for this, which is related to the reason for the lack of substitution in the systems
TABLE 3: Interatomic distances $(\AA)$ in $\mathrm{Pb}_{(8-x)} \mathrm{Na}_{2} \mathrm{Sm}_{x}\left(\mathrm{VO}_{4}\right)_{6} \mathrm{O}_{(x / 2)}$.

\begin{tabular}{lcc}
\hline Composition, $x$ & $x=0$ & $x=0.15$ \\
\hline $\mathrm{Pb}(1)-\mathrm{O}(1) \times 3$ & $2.460(11)$ & $2.538(12)$ \\
$\mathrm{Pb}(1)-\mathrm{O}(2) \times 3$ & $2.899(13)$ & $2.806(13)$ \\
$\mathrm{Pb}(1)-\mathrm{O}(3) \times 3$ & $3.042(12)$ & $2.988(12)$ \\
$\langle\mathrm{Pb}(1)-\mathrm{O}(1-3)\rangle$ & $2.800(4)$ & $2.777(4)$ \\
$\mathrm{Pb}(2)-\mathrm{O}(1)$ & $2.74(2)$ & $2.74(2)$ \\
$\mathrm{Pb}(2)-\mathrm{O}(2)$ & $2.21(2)$ & $2.21(2)$ \\
$\mathrm{Pb}(2)-\mathrm{O}(3) \times 2$ & $2.555(10)$ & $2.518(10)$ \\
$\mathrm{Pb}(2)-\mathrm{O}(3) \times 2$ & $2.598(11)$ & $2.677(12)$ \\
$\langle\mathrm{Pb}(2)-\mathrm{O}(1-3)\rangle$ & $2.543(6)$ & $2.557(7)$ \\
$\mathrm{V}-\mathrm{O}(1)$ & $1.67(2)$ & $1.59(2)$ \\
$\mathrm{V}-\mathrm{O}(2)$ & $1.66(2)$ & $1.76(2)$ \\
$\mathrm{V}-\mathrm{O}(3) \times 2$ & $1.664(11)$ & $1.652(11)$ \\
$\langle\mathrm{V}-\mathrm{O}\rangle$ & $1.665(9)$ & $1.664(9)$ \\
$\mathrm{Pb}(2)-\mathrm{Pb}(2) \times 2$ & $4.385(3)$ & $4.384(3)$ \\
\hline
\end{tabular}

Note: data are given for the solid solution with $x=0$ and $x=0.15$; hence, interatomic distances for the intermediate compositions will be within an error.

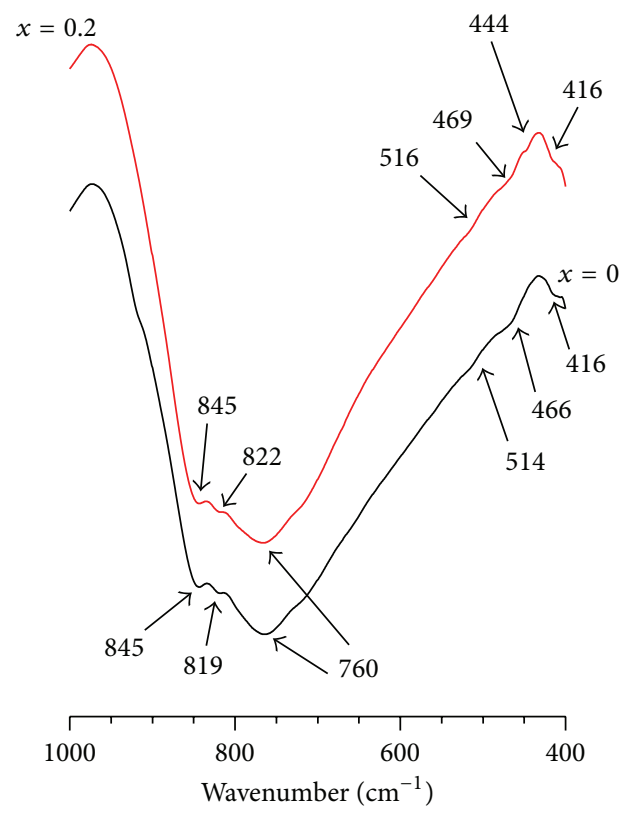

FIgURE 2: Part of IR spectra for the samples $\mathrm{Pb}_{(8-x)} \mathrm{Na}_{2} \mathrm{Sm}_{x}\left(\mathrm{VO}_{4}\right)_{6} \mathrm{O}_{(x / 2)}$ with $x=0$ and $x=0.2$ in the wavenumber range from 1000 to $400 \mathrm{~cm}^{-1}$.

$\mathrm{Pb}_{(10-x)} \mathrm{Ln}_{x}\left(\mathrm{ZO}_{4}\right)_{6}(\mathrm{OH})_{(2-x)} \mathrm{O}_{x}$, lies in the electronic structure of lead. Unlike alkaline earth elements apatites, in lead apatites $\left(\mathrm{Pb}_{10}\left(\mathrm{ZO}_{4}\right)_{6}(\mathrm{OH})_{2}\right)$, stereochemically active lone electron pairs experience repulsive forces from $\mathrm{OH}^{-}$ ions, located in the structural channels. The substitution under the cheme $\mathrm{Pb}^{2+}+\mathrm{OH}^{-} \rightarrow \mathrm{Na}^{+}+\square$ results in decreasing the number of $\mathrm{OH}^{-}$ions and the number of lone electron pairs in the structure, thereby decreasing repulsion and promoting a more compact structure. Indeed, minimal $\mathrm{Pb}-\mathrm{O}$ distances 2.210 and $2.218 \AA$ [13] in the 


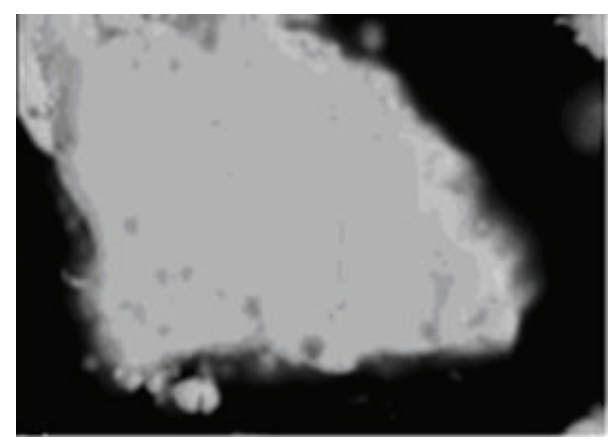

(a)

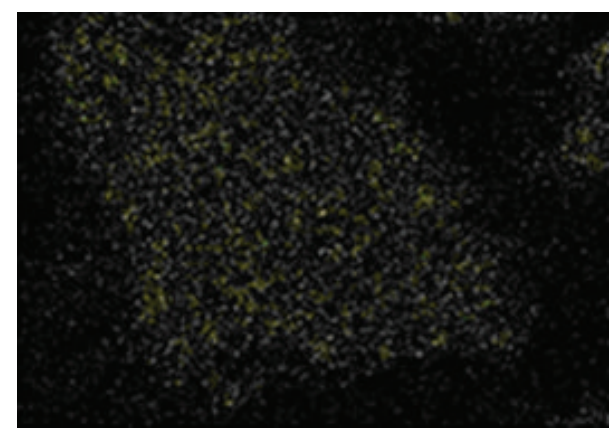

(c)

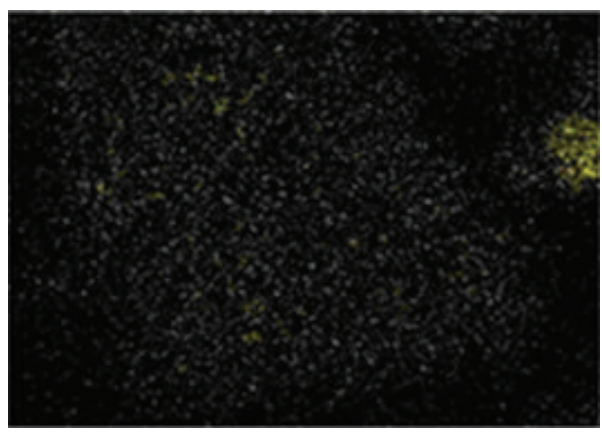

(e)

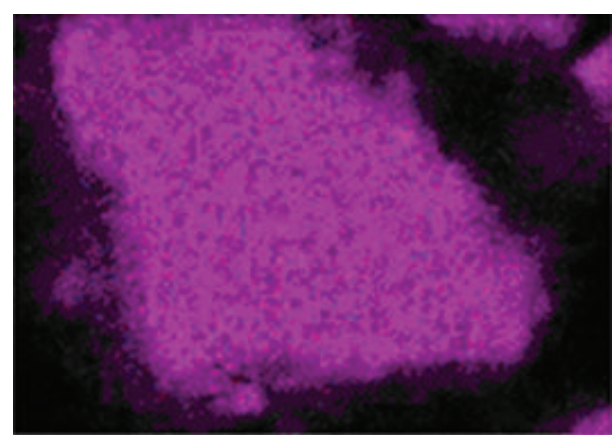

(b)

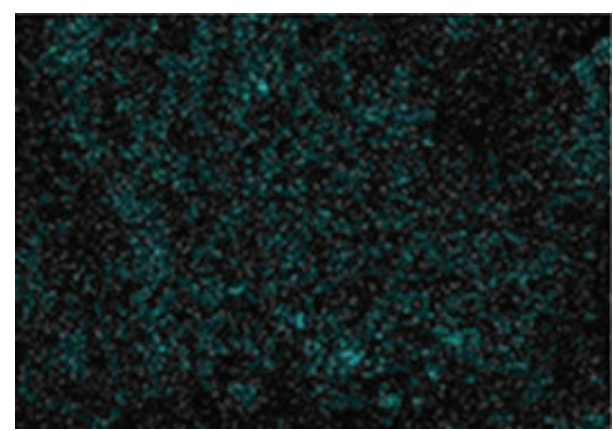

(d)

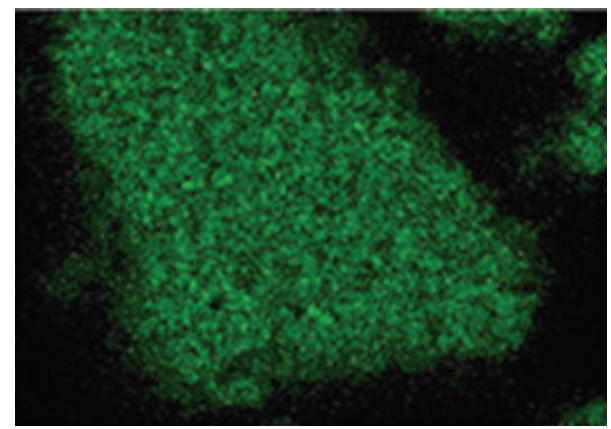

(f)

FIgure 3: Microphotograph of (a) $\mathrm{Pb}_{7.8} \mathrm{Na}_{2} \mathrm{Sm}_{0.2}\left(\mathrm{VO}_{4}\right)_{6} \mathrm{O}_{0.1}$ and distribution of the elements overits surface obtained in the characteristic $\mathrm{X}$-ray of (b) $\mathrm{Pb},(\mathrm{c}) \mathrm{Na}$, (d) O, (e) Sm, and (f) V.

vanadates $\mathrm{Pb}_{8} \mathrm{Na}_{2}\left(\mathrm{VO}_{4}\right)_{6}$ and $\mathrm{Pb}_{8} \mathrm{~K}_{2}\left(\mathrm{VO}_{4}\right)_{6}$ are significantly less than the $2.35 \AA \mathrm{Pb}-\mathrm{O}$ distance in $\mathrm{Pb}_{10}\left(\mathrm{VO}_{4}\right)_{6}(\mathrm{OH})_{2}$ [12]. Thus, in this case, the change in cell parameters is primarily influenced not by the size of the structural units but by the nature of the chemical bond. Rietveld method crystal structure refinement has established that sodium and samarium ions in $\mathrm{Pb}_{(8-x)} \mathrm{Na}_{2} \mathrm{Sm}_{x}\left(\mathrm{VO}_{4}\right)_{6} \mathrm{O}_{(x / 2)}$ occupy half of the $\mathrm{M}(1)$ position and lead ions occupy the second half of $\mathrm{M}(1)$ position. Position $\mathrm{M}(2)$ is fully occupied by the lead ions. These findings are in agreement with previous work [13] for $\mathrm{Pb}_{8} \mathrm{Na}_{2}\left(\mathrm{VO}_{4}\right)_{6}$. The average interatomic distances $\mathrm{Pb}(2)-\mathrm{O}(1-3), \mathrm{V}-\mathrm{O}$, and $\mathrm{Pb}(2)-\mathrm{Pb}(2)$ do not change substantially as $x$ values increase and only $\mathrm{Pb}(1)-\mathrm{O}(1-3)$ decreases from 2.800 (4) to $2.777(4)$ due to the substitution of smaller samarium ions into the $\mathrm{Pb}(1)$ position according to crystal structure refinement (Table 3).

IR spectra of $\mathrm{Pb}_{8} \mathrm{Na}_{2}\left(\mathrm{VO}_{4}\right)_{6}$ and a solid solution $\mathrm{Pb}_{7.8} \mathrm{Na}_{2} \mathrm{Sm}_{0.2}\left(\mathrm{VO}_{4}\right)_{6} \mathrm{O}_{0.1}$ in the wave number range from
1000 to $400 \mathrm{~cm}^{-1}$ are shown in Figure 2. The absorption bands at 760,819, and $845 \mathrm{~cm}^{-1}$ and bands at 416, 466, and $514 \mathrm{~cm}^{-1}$ can be assigned to $\nu_{3}$ and $\nu_{4}$ vibrations of $\mathrm{VO}_{4}{ }^{3-}$ ions $[11,12,16]$. As a result of substitution of samarium for lead, frequency of the $v_{4}$ band increases by $2-3 \mathrm{~cm}^{-1}$ and frequency of the $v_{3}\left(819 \mathrm{~cm}^{-1}\right)$ band increases by $3 \mathrm{~cm}^{-1}$. Furthermore, the spectrum of the solid solution has an additional band at $444 \mathrm{~cm}^{-1}$ not detected previously in studies on nonmodified lead apatite $[11,12]$. However, in studies of substitutions in $\mathrm{Ca}_{10-x} \mathrm{La}_{x}\left(\mathrm{PO}_{4}\right)_{6}(\mathrm{OH})_{y}$ [6] and $\mathrm{Sr}_{10-x} \mathrm{Eu}_{x}\left(\mathrm{PO}_{4}\right)_{6}(\mathrm{OH})_{2-x} \mathrm{O}_{x}$ [17], additional bands were detected in this frequency region and were assigned to vibrations of $\mathrm{La}-\mathrm{O}$ and $\mathrm{Eu}-\mathrm{O}$, respectively.

Therefore, the band at $444 \mathrm{~cm}^{-1}$ can be assigned to vibrations of Sm-O.

Scanning electron microscopy of the synthesized compounds (e.g., Figure 3) shows that the elements are uniformly 
TABLE 4: Results of elemental analysis for the samples $\mathrm{Pb}_{(8-x)} \mathrm{Na}_{2} \mathrm{Sm}_{x}\left(\mathrm{VO}_{4}\right)_{6} \mathrm{O}_{(x / 2)}$ (wt.\%).

\begin{tabular}{|c|c|c|c|c|c|c|c|c|c|c|}
\hline \multirow{2}{*}{$x$} & \multicolumn{2}{|c|}{$\mathrm{V}$} & \multicolumn{2}{|c|}{$\mathrm{Pb}$} & \multicolumn{2}{|c|}{$\mathrm{Sm}$} & \multicolumn{2}{|c|}{$\mathrm{Na}$} & \multicolumn{2}{|c|}{$\mathrm{O}$} \\
\hline & exp. & theor. & exp. & theor. & exp. & theor. & exp. & theor. & exp. & theor. \\
\hline 0 & 13.62 & 12.77 & 69.99 & 69.26 & - & - & 1.93 & 1.92 & 14.46 & 16.05 \\
\hline 0.2 & 14.70 & 12.82 & 66.73 & 67.81 & 0.64 & 1.26 & 3.25 & 1.93 & 14.69 & 16.18 \\
\hline $0^{*}$ & 12.65 & 12.77 & 68.95 & 69.26 & - & - & 1.86 & 1.92 & 16.45 & 16.05 \\
\hline $0.2^{*}$ & 13.09 & 12.82 & 66.05 & 67.81 & 1.31 & 1.26 & 2.31 & 1.93 & 17.14 & 16.18 \\
\hline
\end{tabular}

*Elemental composition was determined using Rietveld crystal structure refinement.

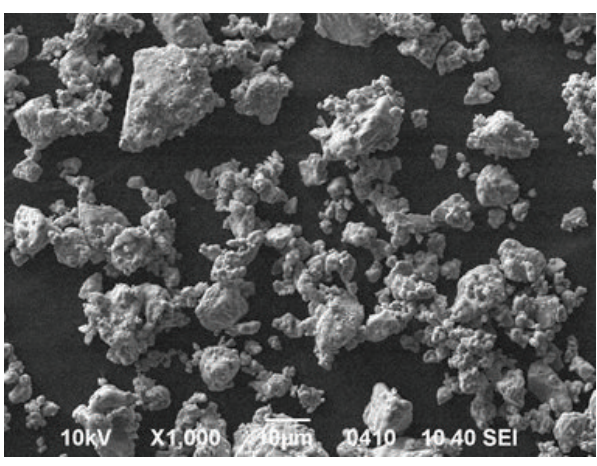

(a)

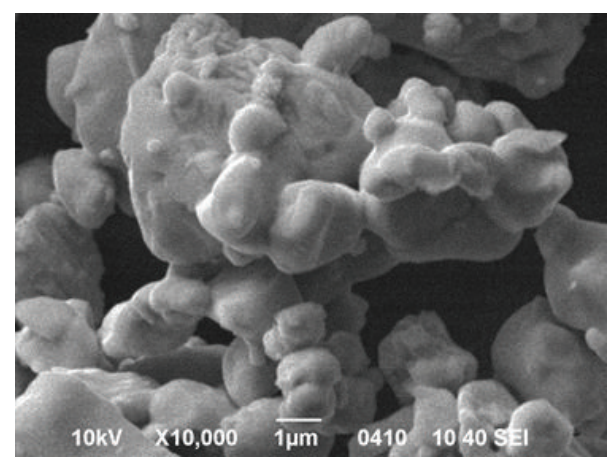

(b)

FIgure 4: Microphotograph of the sample $\mathrm{Pb}_{7.8} \mathrm{Na}_{2} \mathrm{Sm}_{0.2}\left(\mathrm{VO}_{4}\right)_{6} \mathrm{O}_{0.1}$ (a) resolution $\times 1,000$ and (b) resolution $\times 10,000$.

distributed over the surface of the powder particles. Available irregularity related to its relief.

The powder is finely dispersed, the aggregate size is about $10 \mu \mathrm{m}$ (Figure $4(\mathrm{a})$ ), and the grain size is about $1.0 \mu \mathrm{m}$ (Figure 4(b)).

Since the lead oxide can sublime in the synthesis, elemental microanalysis by scanning electron microscopy was performed on 20 samples each of compositions $x=0$ and $x=0.2$ (Table 4 ). The experimental results are in satisfactory agreement with the calculated values. The analytical error in these measurements is comparable to those reported in [18] for compounds with apatite structure studied by the same method. In addition, the elemental composition data obtained by the crystal structure refinement (Table 4) is consistent with the results of microanalysis; if sublimation of lead oxide did take place, it was only to a minor extent.

To evaluate electrical conductivity of the synthesized apatites, $\log \sigma$ was plotted against 1/T. Two such plots for compositions with $x=0$ and $x=0.2$ are given in Figure 5. In contrast to [11], in which for $\mathrm{Pb}_{8} \mathrm{Na}_{2}\left(\mathrm{VO}_{4}\right)_{6}$ only one linear plot was obtained in the temperature range $350-456^{\circ} \mathrm{C}$, we have determined the conductivity of $\mathrm{Pb}_{8} \mathrm{Na}_{2}\left(\mathrm{VO}_{4}\right)_{6}$ in the temperature range $300-600^{\circ} \mathrm{C}$. Four plots were obtained, yielding activation energy values 0.49 , $1.61,4.84$, and $1.41 \mathrm{eV}$ in the temperature ranges $300-440$, $440-480,480-530$, and $530-600^{\circ} \mathrm{C}$, respectively (Table 5). The values of activation energy and electrical conductivity for unmodified $\mathrm{Pb}_{8} \mathrm{Na}_{2}\left(\mathrm{VO}_{4}\right)_{6}$ in the temperature range of $300-440^{\circ} \mathrm{C}$ (Table 6) do not differ significantly from the results on conductivity obtained in [11] $\left(0.37 \cdot 10^{-5}, 0.67 \cdot 10^{-5}\right.$, and $1.30 \cdot 10^{-5}$ at 350,400 , and $450^{\circ} \mathrm{C}$ and activation energy $0.59 \mathrm{eV})$. The activation energies for $\mathrm{Pb}_{8} \mathrm{Na}_{2}\left(\mathrm{VO}_{4}\right)_{6}$ ranges
TABle 5: Activation energy $(\mathrm{eV})$ for the samples $\mathrm{Pb}_{(8-x)} \mathrm{Na}_{2} \mathrm{Sm}_{x}\left(\mathrm{VO}_{4}\right)_{6} \mathrm{O}_{(x / 2)}$.

\begin{tabular}{lcccc}
\hline$x=0$ & $x=0.05$ & $x=0.1$ & $x=0.15$ & $x=0.2$ \\
\hline $0.49\left(300-440^{\circ} \mathrm{C}\right)^{*}$ & 0.52 & 0.61 & 0.69 & 0.79 \\
$1.61\left(440-480^{\circ} \mathrm{C}\right)^{*}$ & 0.98 & 1.10 & 1.32 & 1.49 \\
$4.84\left(480-530^{\circ} \mathrm{C}\right)^{*}$ & 3.18 & 2.62 & 2.44 & 2.49 \\
$1.41\left(530-600^{\circ} \mathrm{C}\right)^{*}$ & 2.89 & 2.20 & 1.55 & 1.06 \\
\hline
\end{tabular}

${ }^{*}$ Temperature ranges are given for $\mathrm{Pb}_{8} \mathrm{Na}_{2}\left(\mathrm{VO}_{4}\right)_{6}(x=0)$; they are approximately the same for other compositions.

in the temperatures $440-480$ and $530-600^{\circ} \mathrm{C}$ are 1.61 and $1.41 \mathrm{eV}$ and belong to the range $1.21-2.07 \mathrm{eV}$ also found for the solid solution $\mathrm{Pb}_{8} \mathrm{~K}_{2-x} \mathrm{Na}_{x}\left(\mathrm{PO}_{4}\right)_{6}$ with the apatite structure having a cationic conductivity [19]. However, the activation energy in the temperature range $480-530^{\circ} \mathrm{C}$ is significantly higher $(4.84 \mathrm{eV})$ and is not typical of cationic conductivity. Somewhat lower activation energy $(3.85 \mathrm{eV})$ and a similar dependence of the electrical conductivity on temperature were previously described for compounds with the apatite structure $\mathrm{Pb}_{4.8} \mathrm{Bi}_{1.6} \mathrm{Na}_{3.6}\left(\mathrm{PO}_{4}\right)_{6}[20]$.

On the basis of its crystal structure study at $900 \mathrm{~K}$, such large activation energy for ionic conductivity is thought to result from the transfer of sodium cations from their positions at normal conditions to the center of the channel. The cationic conductivity in $\mathrm{Pb}_{4.8} \mathrm{Bi}_{1.6} \mathrm{Na}_{3.6}\left(\mathrm{PO}_{4}\right)_{6}$ was found within the entire temperature range.

As the replacement of samarium for lead takes place, activation energy varies depending on the value of $x$ and on temperature. Thus, in the temperature range $300-440^{\circ} \mathrm{C}$, activation energy gradually increases with increasing $x$ 
TABLE 6: Conductivity $\left(\mathrm{S} \cdot \mathrm{cm}^{-1}\right)$ and relative density $(\rho, \%)$ for the samples $\mathrm{Pb}_{(8-x)} \mathrm{Na}_{2} \mathrm{Sm}_{x}\left(\mathrm{VO}_{4}\right)_{6} \mathrm{O}_{(x / 2)}$.

\begin{tabular}{lccccccc}
\hline$x$ & $350^{\circ} \mathrm{C}$ & $400^{\circ} \mathrm{C}$ & $450^{\circ} \mathrm{C}$ & $500^{\circ} \mathrm{C}$ & $550^{\circ} \mathrm{C}$ & $600^{\circ} \mathrm{C}$ & $\rho, \%$ \\
\hline 0 & $0.38 \cdot 10^{-5}$ & $0.52 \cdot 10^{-5}$ & $0.86 \cdot 10^{-5}$ & $2.5 \cdot 10^{-5}$ & $17 \cdot 10^{-5}$ & $30 \cdot 10^{-5}$ & 94 \\
0.05 & $0.18 \cdot 10^{-5}$ & $0.26 \cdot 10^{-5}$ & $0.42 \cdot 10^{-5}$ & $0.8 \cdot 10^{-5}$ & $3.5 \cdot 10^{-5}$ & $11 \cdot 10^{-5}$ \\
0.10 & $0.27 \cdot 10^{-5}$ & $0.43 \cdot 10^{-5}$ & $0.73 \cdot 10^{-5}$ & $1.7 \cdot 10^{-5}$ & $5.6 \cdot 10^{-5}$ & $14 \cdot 10^{-5}$ \\
0.15 & $0.33 \cdot 10^{-5}$ & $0.55 \cdot 10^{-5}$ & $0.98 \cdot 10^{-5}$ & $3.2 \cdot 10^{-5}$ & $8.9 \cdot 10^{-5}$ & $17 \cdot 10^{-5}$ & 95 \\
0.20 & $0.53 \cdot 10^{-5}$ & $0.90 \cdot 10^{-5}$ & $1.80 \cdot 10^{-5}$ & $5.1 \cdot 10^{-5}$ & $12 \cdot 10^{-5}$ & $19 \cdot 10^{-5}$ & 95 \\
\hline
\end{tabular}

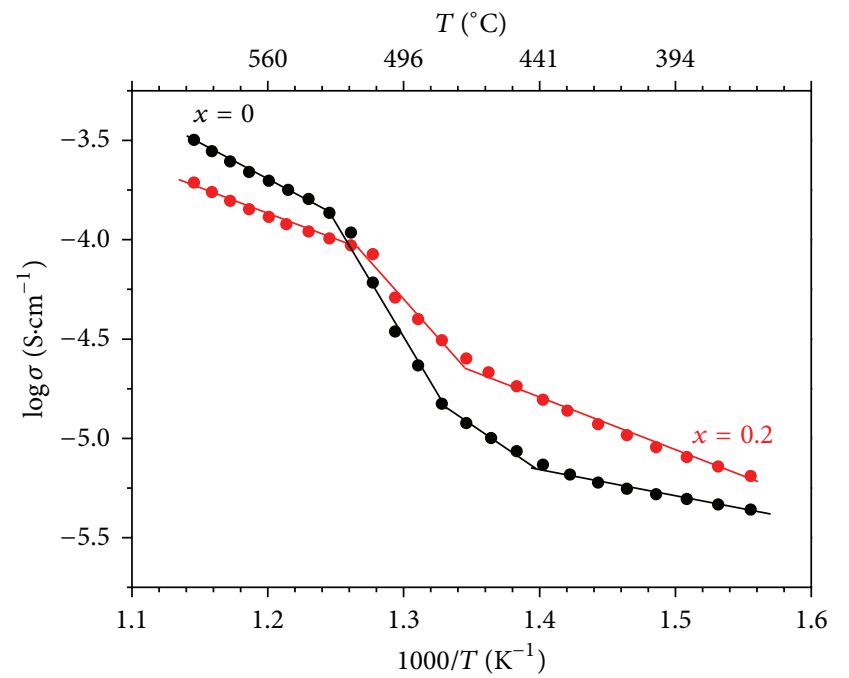

FIGURE 5: Logarithm of conductivity, $\log \sigma\left(\mathrm{S} \cdot \mathrm{cm}^{-1}\right)$ as a function of $1000 / \mathrm{T},\left(\mathrm{K}^{-1}\right)$ for $\mathrm{Pb}_{(8-x)} \mathrm{Na}_{2} \mathrm{Sm}_{x}\left(\mathrm{VO}_{4}\right)_{6} \mathrm{O}_{(x / 2)}$.

(Table 5). At higher temperatures, the most significant change in activation energy, about $30-100 \%$, takes place with the substitution of lead by $0.62 \mathrm{wt}$. \% (at $x=0.05$ ). In the temperature range of $440-480^{\circ} \mathrm{C}$ it first decreases significantly from 1.61 to $0.98 \mathrm{eV}$ and then gradually increases to $1.49 \mathrm{eV}$ with increasing content of samarium. In the temperature range of $530-600^{\circ} \mathrm{C}$, the opposite takes place; activation energy initially rises sharply from 1.41 to $2.89 \mathrm{eV}$ and then gradually decreases to $1.06 \mathrm{eV}$. Finally, in the temperature range of $480-530^{\circ} \mathrm{C}$ the activation energy decreases from the greatest magnitude of 4.84 to $2.44-2.49 \mathrm{eV}$.

The electrical conductivity of synthesized apatites (Table 6) decreases by $50 \%$ to $80 \%$ throughout almost the entire temperature range in going from pure $\mathrm{Pb}$ apatite $(x=0)$ to a Sm substitution of $x=0.05$ and then increases as samarium content increases (Table 6). In the temperature range $450-500^{\circ} \mathrm{C}$, the conductivity for the limiting composition $(x=0.2)$ is twice as much as that of $\mathrm{Pb}_{8} \mathrm{Na}_{2}\left(\mathrm{VO}_{4}\right)_{6}$.

\section{Conclusions}

The substitution of samarium for lead in $\mathrm{Pb}_{(8-x)} \mathrm{Na}_{2} \mathrm{Sm}_{x}\left(\mathrm{VO}_{4}\right)_{6} \mathrm{O}_{(x / 2)}$ occurs in the region $0 \leq x \leq 0.2$. Conductivity decreases sharply by $50 \%$ to $80 \%$ with initial Sm substitution for $\mathrm{Pb}$ (from $x=0$ to $x=0.05$ ) and then increases with $\mathrm{x}$ over the entire temperature range. Conductivity for the limiting composition of the solid solution $(x=0.2)$ is approximately twice as much as it is in $\mathrm{Pb}_{8} \mathrm{Na}_{2}\left(\mathrm{VO}_{4}\right)_{6}$ over the temperature range $450-500^{\circ} \mathrm{C}$. These results may be of practical importance in the application of the modified solid solutions of lead sodium vanadate as solid electrolytes and luminescent materials.

\section{Conflict of Interests}

The authors declare that there is no conflict of interests regarding the publication of this paper.

\section{Acknowledgment}

The authors are grateful to Dr. Steven Losh for editorial help.

\section{References}

[1] D. Grossin, S. Rollin-Martinet, C. Estournès et al., "Biomimetic apatite sintered at very low temperature by spark plasma sintering: physico-chemistry and microstructure aspects," Acta Biomaterialia, vol. 6, no. 2, pp. 577-585, 2010.

[2] J. Zhang, H. Liang, R. Yu, H. Yuan, and Q. Su, "Luminescence of $\mathrm{Ce}^{3+}$-activated chalcogenide apatites $\mathrm{Ca}_{10}\left(\mathrm{PO}_{4}\right)_{6} \mathrm{Y}(\mathrm{Y}=\mathrm{S}, \mathrm{Se})$," Materials Chemistry and Physics, vol. 114, no. 1, pp. 242-246, 2009.

[3] H. Yoshioka, Y. Nojiri, and S. Tanase, "Ionic conductivity and fuel cell properties of apatite-type lanthanum silicates doped with $\mathrm{Mg}$ and containing excess oxide ions," Solid State Ionics, vol. 179, no. 38, pp. 2165-2169, 2008.

[4] S. Kale, S. Kahandal, S. Disale, and R. Jayaram, "Conventional and microwave-assisted multicomponent reaction of alkyne, halide and sodium azide catalyzed by copper apatite as heterogeneous base and catalyst in water," Current Chemistry Letters, vol. 1, pp. 69-80, 2012.

[5] W. L. Bragg and G. F. Klaringbull, Crystal Structure of Minerals, Peace, Moscow, Russia, 1967.

[6] A. Serret, M. V. Cabañas, and M. Vallet-Regi, "Stabilization of calcium oxyapatites with lanthanum(III)-created anionic vacancies," Chemistry of Materials, vol. 12, no. 12, pp. 3836-3841, 2000.

[7] E. Get'man, N. Yablochkova, S. Loboda et al., "Isomorphous substitution of europium for strontium in the structure of synthetic hydroxovanadate," Journal of Solid State Chemistry, vol. 181, pp. 264-270, 2008.

[8] L. I. Ardanova, E. I. Get'Man, S. N. Loboda et al., "Isomorphous substitutions of rare earth elements for calcium in synthetic hydroxyapatites," Inorganic Chemistry, vol. 49, no. 22, pp.1068710693, 2010. 
[9] L. H. Brixner and P. E. Bierstedt, "Optical and electronic properties of some new rare earth-doped lead sodium apatites," Journal of Solid State Chemistry, vol. 13, no. 1-2, pp. 24-31, 1975.

[10] R. M. H. Verbeeck, C. J. Lassuyt, H. J. M. Heijligers, F. C. M. Driessens, and J. W. G. A. Vrolijk, "Lattice parameters and cation distribution of solid solutions of calcium and lead hydroxyapatite," Calcified Tissue International, vol. 33, no. 1, pp. 243-247, 1981.

[11] E. Chakroun-Ouadhour, R. Ternane, D. B. Hassen-Chehimi, and M. Trabelsi-Ayadi, "Synthesis, characterization and electrical properties of a lead sodium vanadate apatite," Materials Research Bulletin, vol. 43, no. 8-9, pp. 2451-2456, 2008.

[12] J. G. Eon, C. B. Boechat, A. M. Rossi, J. Terra, and D. E. Ellis, "A structural analysis of lead hydroxyvanadinite," Physical Chemistry Chemical Physics, vol. 8, no. 15, pp. 1845-1851, 2006.

[13] M. Azrour, L. El Ammari, Y. le Fur, and B. Elouadi, "Etude structurale d'orthovanadates d'alcalins et de plomb cristallisant avec la structure apatite lacunaire," Journal of Solid State Chemistry, vol. 141, no. 2, pp. 373-377, 1998.

[14] L. G. Akselrud, P. Y. Zavalii, N. Y. Grin, V. K. Pecharsky, B. Baumgartner, and E. Wolfel, "Use of the CSD program package for structure determination from powder data," Materials Science Forum, vol. 133-136, pp. 335-340, 1993, http://wincsd.eu.

[15] R. D. Shannon, "Revised effective ionic radii and systematic studies of interatomic distances in halides and chalcogenides," Acta Crystallographica A, vol. 32, pp. 751-767, 1976.

[16] C. B. Boechat, J. G. Eon, A. M. Rossi et al., "Structure of vanadate in calcium phosphate and vanadate apatite solid solutions," Physical Chemistry Chemical Physics, vol. 2, no. 18, pp. 42254230, 2000.

[17] J. L. Lacout, A. Taitai, and G. Bonel, "Coupled substitution $(\mathrm{Eu}, \mathrm{O})$ in strontium hydroxyapatite," Comptes Rendus de l'Académie des Sciences, Série 2, vol. 304, no. 13, pp. 699-702, 1987.

[18] D. Arcos, J. Rodrıguez-Carvajal, and M. Vallet-Regi, "Crystalchemical characteristics of silicon-neodymium substituted hydroxyapatites studied by combined X-ray and neutron powder diffraction," Chemical Materials, vol. 17, pp. 57-64, 2005.

[19] A. Laghzizil, P. Barboux, and A. Bouhaouss, "Cationic conductivity and structural studies in the $\mathrm{Pb}_{8} \mathrm{~K}_{2-x} \mathrm{Na}_{x}\left(\mathrm{PO}_{4}\right)_{6}$ system," Solid State Ionics, vol. 128, no. 1-4, pp. 177-181, 2000.

[20] B. Hamdi, H. El Feki, A. Ben Salah, P. Salles, P. Baules, and J. M. Savariault, "Ionic conductivity and phase transition in $\mathrm{Pb}_{4.8} \mathrm{Bi}_{1.6} \mathrm{Na}_{3.6}\left(\mathrm{PO}_{4}\right)_{6}$, an apatite-type compound," Solid State Ionics, vol. 177, no. 17-18, pp. 1413-1420, 2006. 

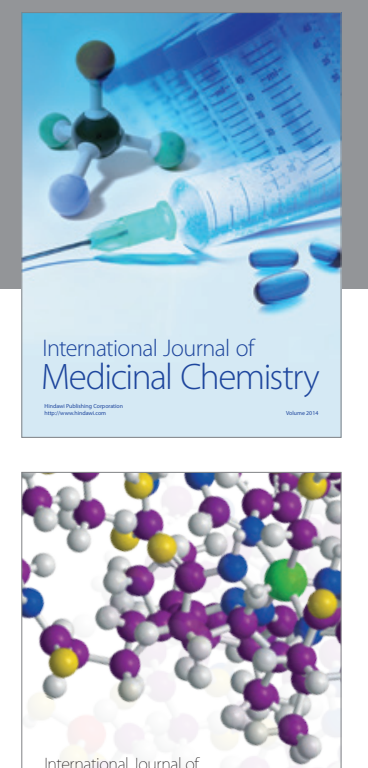

\section{Carbohydrate} Chemistry

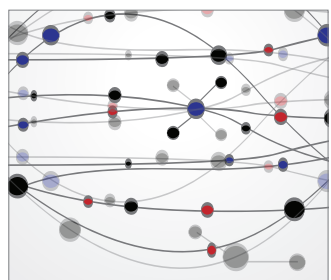

The Scientific World Journal
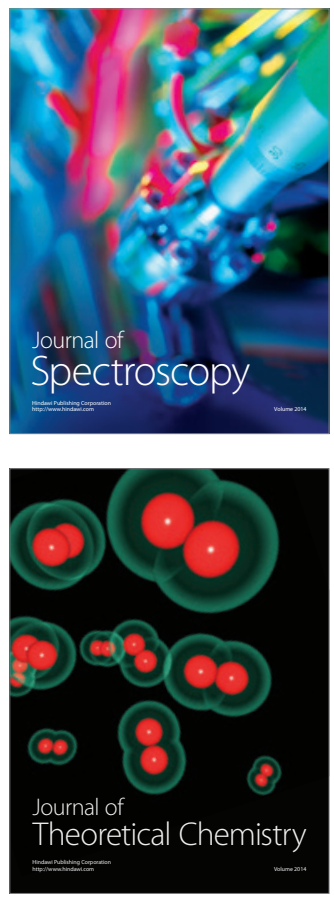
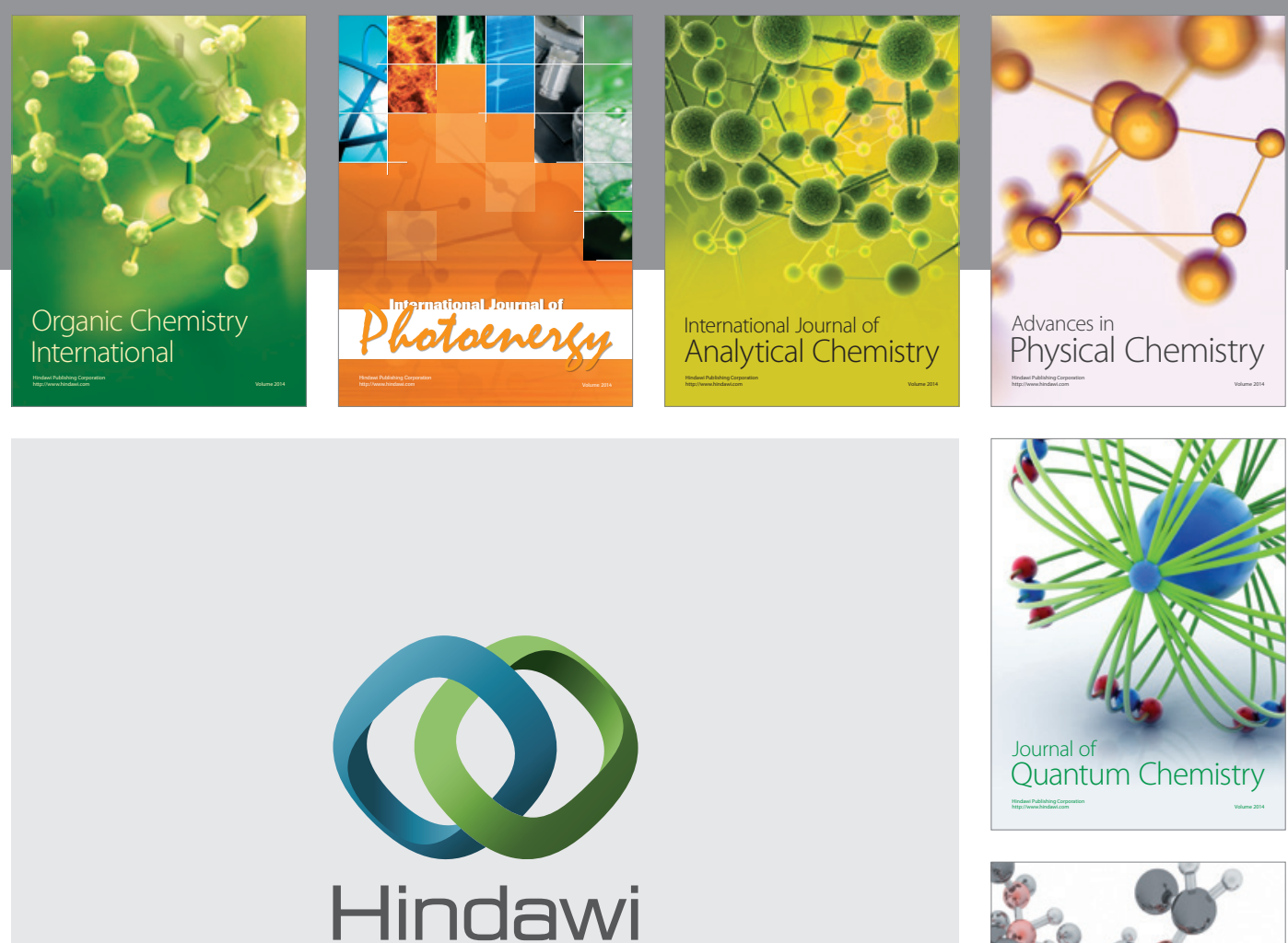

Submit your manuscripts at

http://www.hindawi.com

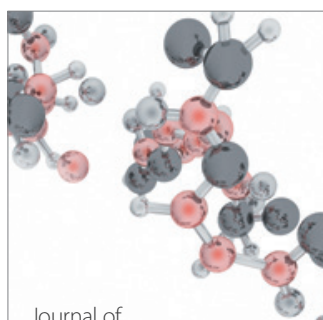

Analytical Methods

in Chemistry

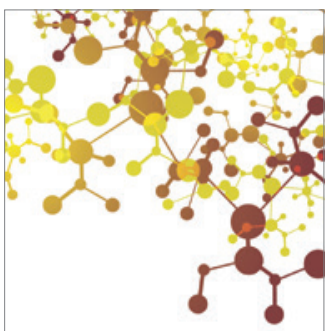

Journal of

Applied Chemistry

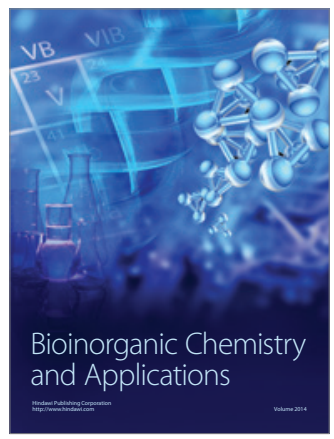

Inorganic Chemistry
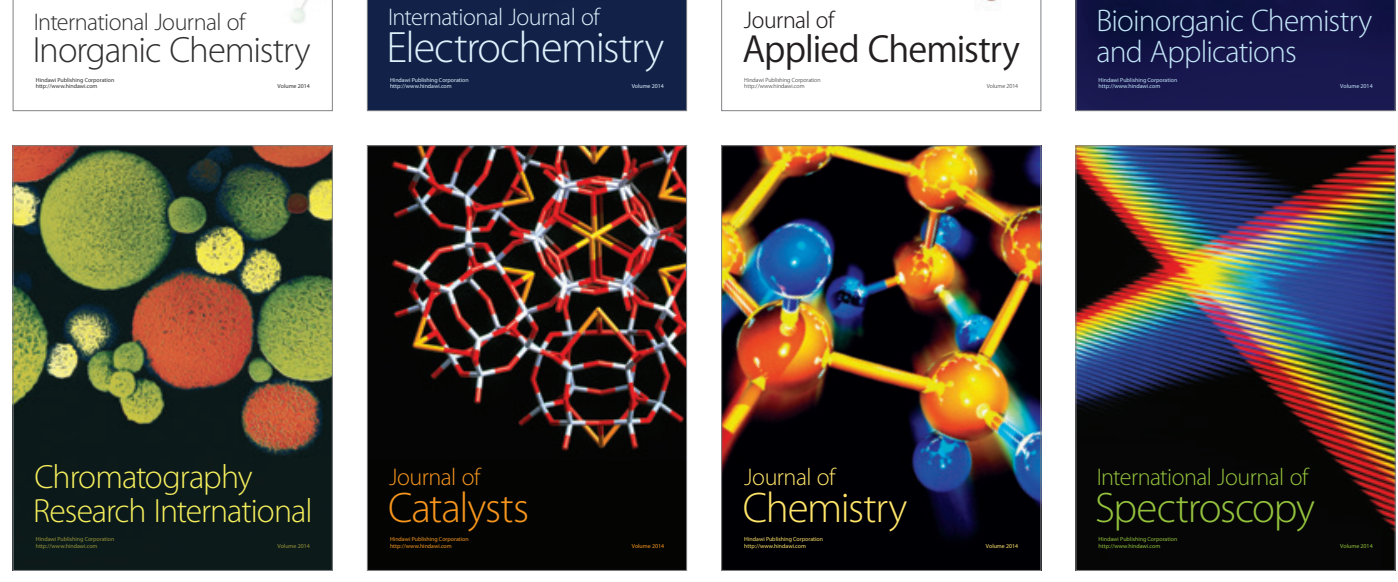